\title{
The influence of potential outcomes of corporate social responsibility engagement factors on SME competitiveness
}

\author{
E. Venter*, P. Turyakira and E.E. Smith \\ P O Box 77000, Nelson Mandela Metropolitan University, NMMU, Port Elizabeth, Tel: +27-41-5042875/2204 \\ *To whom all correspondence should be addressed \\ Elmarie.Venter@nmmu.ac.za
}

\begin{abstract}
While SMEs are globally recognised for their importance in the social and economic development of many economies, their survival and competitiveness has remained a cause for concern. More than half of SMEs in Uganda fail during their first year. Analytical and empirical research on appropriate strategies for SMEs' competitiveness in Uganda is limited. The potential outcomes of CSR engagement such as employee satisfaction, business reputation, and customer loyalty have been found to be positively related to the competitiveness of SMEs. The primary objective of this article is to identify and empirically test the factors that influence the competitiveness of SMEs in Uganda. A structured selfadministered questionnaire was distributed to 750 potential SME respondents. The respondents were identified using purposive sampling technique, and the data were collected from 383 usable questionnaires. An exploratory factor analysis was conducted, and Cronbach-alpha coefficients calculated to determine the discriminant validity and reliability of the measuring instrument. Correlations were analysed using Structural Equation Modeling. The empirical results of this study indicate that Employee satisfaction, Business reputation, Customer loyalty and Stakeholder trust significantly impact the competitiveness of SMEs.
\end{abstract}

\section{Introduction}

There is a growing recognition of the important role small and medium enterprises (SMEs) play in economic development globally (Kongolo, 2010: 2288; Muhammad, Char, Yasoa \& Hassan, 2010: 66). SMEs are often described as efficient and productive job creators, wealth creators, and engines of economic growth (Abor \& Quartey, 2010: 218; Amin \& Banerjee, 2007: 59). In Africa, where the private sector in general is not well developed, SMEs could play a critical role in stimulating economic development and alleviating poverty (Beyene, 2002: 1).

While the contributions of SMEs to social and economic development are generally acknowledged, they face many obstacles that limit their long-term survival (Okpara \& Wynn, 2007: 195). Their competitiveness is largely constrained by a number of factors, such as a lack of access to appropriate technology; limited access to international markets; weak institutional capacity; lack of management skills and training; lack of a professional and competent workforce; lack of a substantial orientation towards the domestic market; and lack of finance (Abor \& Quartey, 2010: 218; Saleh \& Ndubisi, 2006: 10; Okpara \& Wynn, 2007: 195). As such, the high failure rate among SMEs has remained a cause for concern in developing countries, especially in Uganda (Harorimana, 2009: 71; Hatega, 2007: 4; Tushabomwe-Kazooba, 2006: 2). Analytical and practical case studies on appropriate strategies that can aid the competitiveness of SMEs in Uganda are also limited. Even though SMEs tend to attract motivated managers, they can hardly compete with larger firms (Abor \& Quartey, 2010: 224).

Globalization of markets and the turbulent business environment have increased the level of competitiveness, which is increasingly putting greater pressure on SMEs to acquire and increase their competitive advantages (Guzmán, Gutiérrez, Cortes \& Ramírez, 2012: 9). However, owing to global competition, technological advances and changing needs of consumers, competitive paradigms are continuously changing. To remain competitive, businesses need to be able to adapt to new demands from the market and society in which they operate. As such, corporate social responsibility (CSR) can be used as strategic tool to enhance the competitiveness of SMEs (Szabo, 2008: 17).

CSR can positively influence the competitiveness of SMEs through improved products resulting in better customer satisfaction and loyalty, higher motivation and loyalty of employees, and better networking with business partners and access to public funds due to a better business image (Mandl, 2009: 11; Szabo, 2008: 18). The motivation of employees is one of the key factors that affect the progress and success of a business, by keeping employees satisfied on the job (Kishore, Majumdar \& Kiran, 2012: 4). A good business reputation, on the other hand, can benefit SMEs by attracting potential customers, saving the time for establishing business relationship with customers, reducing the transaction cost and creating premium revenue (Zhang, 2009: 33). Creating loyal customers has also become more important due to significant increase in competition and concentrated markets. In this turbulent competitive 
environment, research suggests that building long-term relations with the eustomers is imperative for SME managers (Rehman \& Afsar, 2012: 183). For the purpose of this study, small and medium sized enterprises are considered as businesses which employ more than 5 but fewer than 100 persons, while competitiveness refers to a business's ability to sustain its bong-term performance better than its competitors in the market, as indicated by profitability, market share, sales and growth rate.

\section{Objectives}

The primary objective of this paper is to identify and empirically test the potential outeomes of CSR engagement factors such as employee satisfaction, business reputation, and customer loyalty that influence the competitiveness of SMEs. Based on the fundings, recommendations will be made to assist SMEs to effectively manage activities inside their businesses, which could result in increased competitiveness. This study adds to what is eurrently known about factors that influence the competitiveness of SMEs. It is hoped that by identifying these factors and testing them among SMEs in a developing country, SMEs can use these as possible mechanisms to enhance their competitiveness.

\section{Determinants of SME competitiveness}

While the research on competitiveness has been increasing in popularity amongst scholars, less is known about the competitiveness of SMEs (Szerb \& Utbert, 2009: 1). In today's globalised economy, SMEs are facing ever increasing competitive pressures (Mohammad et al, 2010: 68; Whittaker, Bunns \& Beveren, 2003: 1). They need to gain new market information and knowledge to remain competitive. As such, a common strategy is to develop social networks with other SMEs (Whittaker et al, 2003: 2). Furthermore, the potential outeomes of CSR engagement such as employee satisfaction, business reputation, and customer loyalty have been found to be postively related to the competitiveness of SMEs (Rehman, 2012: 183; Turyakira, 2012: 184).

SMEs ean adopt CSR activities to address consumers' social and environmental concerns, create a favourable corporate inage, and develop a positive relationship with consumers and other stakeholders (Liu \& Zhou, 2009: 4), thereby enhaneing their competitiveness. Hence, this study focuses on Employee satisfaction, Business reputation and Customer loyalty which constitute the independent variables. Employee satisfaction is an important factor for business suecess and to achieve greater competitiveness. If a business wants to function optimally and gain profit, it should have educated, motivated, and therefore satisfied staff, because the suceess of a business lies in its human resourees (Kovatevic, Gajic \& Penic, 2012: 224). In this highly competitive environment, business reputation should be considered as an asset and wealth that gives the business a competitive advantage because the business will be regarded as reliable. Once a business achieves a favourable reputation in the eyes of its eustomers, it will stand out among its competitors to reap benefits, which would in turn further improve its reputation (Awang, 2011: 31). Furthermore, for busmesses to sueceed in this competitive environment, they must fund suitable ways for creating and adding value for their eustomers. SMEs must understand their customers if they are to create competitive advantage and benefit from the loyalty of their customers (Papulova \& Papulova, 2006: 1). These factors ean individually or collectively deternine the competitiveness of SMEs in the long-term in terms of increased sales volume, growth rate, market share and profitability. The proposed hypothesised model, illustrated in Figure 1, illustrates the relationships between the selected factors as independent variables and Increased competitiveness as the dependent variable.

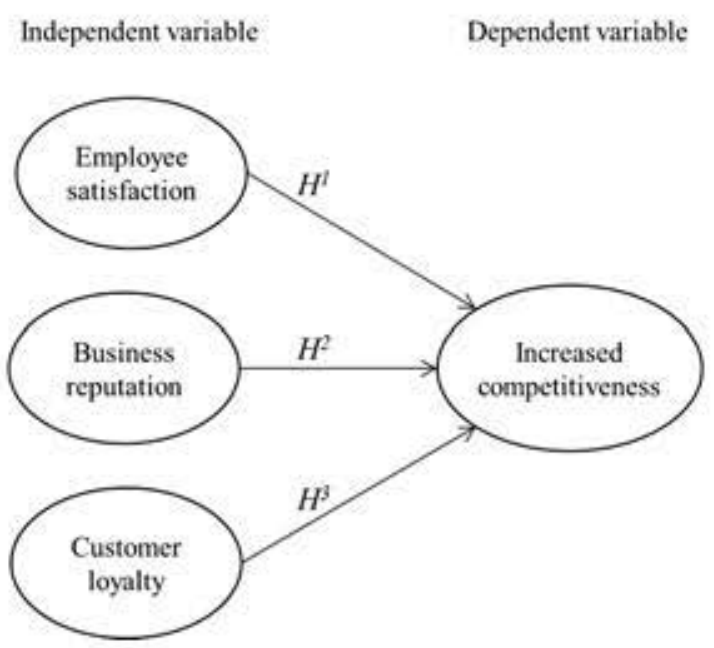

Figure 1: Determinants of increased competitiveness of SMES

In Figure 1 above (the hypothesised model), Employee satisfaction, Business reputation and Customer loyalty (independent variables) impact on the Increased competitiveness of SMEs (dependent variable), which could be measured by sales volume, growth rate, makket share and profitability. These factors will now be discussed in the following paragraphs.

\section{Independent variables}

\section{Employee satisfaction}

In this study, Employee satisfaction refers to the business having employees who see their role in the business as satisfying and enjoying working together in the business. This implies attracting, developing, motivating and retaining qualified and happy employees who feel that they have achieved something with a view of enhaneing a business's competitiveness. There are many factors that influence employee satisfaction sixh as employee benefits, job content and performance appraisal systems, job safety, improved workplace conditions, and the relationship between managers or other employees (Aydin \& Ceylan, 2008: 4). Employee satisfaction represents a component of the suxeess of each business (Diaz-Serrano \& Cabral Vieira, 2005: 3), and more satisfied employees are less likely to 
leave their employer (Gaziouglu \& Tanseel, 2002: 3; Yee, Yeung \& Cheng, 2010: 117). A survey of employees in Novi Sad's Tourist Agencies (Kovačević et al., 2012: 221) revealed that better working conditions and interpersonal relationships provide greater employee satisfaction. Not only do employees feel comfortable, but also better working conditions provide better opportunity for improved job performance and success at work. Employees are more satisfied if they perceive that the reward system as fair and provides equal treatment to all employees, and that more is expected from the fair reward system than from the salary itself (Kovačević et al., 2012: 223). This implies that perceived fairness of the reward system is a more important factor than just salary (Karatepe \& Kilic, 2007).

Furthermore, a survey by Sirota Survey Intelligence (2007: 1) revealed that employees who are satisfied with a business's commitment to their welfare are likely to be more positive, more engaged and more productive than those working for less responsible employers. Similarly, a survey of Canadian SMEs (Princic \& Floyd, 2003: 12) established that good employee relationships are regarded as integral to the success of SMEs. Hence, having loyal employees can be a prerequisite for any successful business. A study in the Taiwan's Shipping Industry established a positive relationship between employee satisfaction and SMEs' competitive advantage (Tsai, Yu \& Fu, 2005: 9). SMEs can use employee benefits to increase employee productivity and, in turn, achieve competitive advantage. Based on thi anecdotal and empirical evidence, the following relationship is hypothesised:

\section{$H^{1}$ : There is a positive relationship between achieving Employee satisfaction and Increased competitiveness of SMES.}

\section{Business reputation}

In this study, Business reputation refers to attributes that form stakeholders' perceptions of the extent to which a business is well known, reliable, trustworthy, reputable and believable. According to Awang (2011: 30), businesses can achieve favourable levels of reputation by being reliable, credible, trustworthy and responsible in the market in the eyes of their stakeholders. The reputation of a business is a collective construct which reflects an aggregated view of individual perceptions (Barnett, Jermier \& Lafferty, 2006: 33). Business reputation is perceived as the strong relationship between the customers and the business, which is viewed as client relationship-building (Omar, Williams \& Lingelbach, 2009: 4). Empirical findings by Helm (2007: 8) among employees showed that commitment to protecting the environment, fair treatment of employees, commitment to charitable and social issues, and qualification of management are the most important business reputation attributes.

A good business reputation can lead to several strategic benefits such as lowering business costs and enabling businesses to charge premium prices; thus increasing its profitability (Walker, 2010: 360). In doing sô, a business's competitiveness is likely to increase in the long-run. Customers are more inclined to purchase the products or services from businesses which they perceive as having fayourable reputation among their competitors (Nguyen \& Leblanc, 2001). Accordingly, business reputation is seen as a potential source of competitive advantage (Davies, Chun \& Kamins, 2010 532). Hence, businesses should focus on building trust and good will to be profitable and competitive.

Business reputation is an important intangible asset that leads to sustainable competitive advantage (Caliskan, Icke \& Ayturk, 2011: 71). According to Eberl and Schwaiger (2005: 6), business reputation is an intangible asset that could generate a competitive advantage in the marketplace, and hence, superior financial performance relative to competitors. An empirical study (Omar et al., 2009: 4) among leading US/UK businesses found that those businesses with a more positive reputation appeared to project their core mission and identity in a more systematic and consistent fashion than businesses with lower reputation rankings. Furthermore, Empirical findings by Shamma and Hassan (2009: 334) highlight vision and leadership, emotional appeal and social and environmental responsibility as the important elements that businesses need to focus on as their reputation progresses. These elements are at the highest level of business reputation and represent an important source of long-term sustainability and competitive advantage. Research findings from both autoregressive profit models and proportional hazards regression models (Roberts \& Dowling, 2002: 14) consistently suggest that successful businesses have a greater chance of sustaining superior performance over time if they also possess relatively good business reputations. Against this background, the following is hypothesised:

\section{$H^{2}$ : There is a positive relationship between Business reputation of SMEs and Increased competitiveness.}

\section{Customer loyalty}

In this study, Customer loyalty refers to a business having loyal and satisfied customers that are willing to support it by recommending its products and are committed to buying its products/services in the future. In an era of intense competitive pressures, many businesses are focusing their efforts on maintaining a loyal customer base. Loyal customers are more likely to engage in repeat purchases from a business or increase their share of purchases from a particular business (Cengiz, Ayyildiz \& Er, 2007: 63). As markets become more competitive, businesses are more likely to attempt to maintain their market share by focusing on retaining current customers (Lee, Lee, \& Feick, 2001: 2). Building customer loyalty should be a business strategy that businesses can use to increase and maximise their share of customers. Customer loyalty does not only help in generating revenues and profits but it also helps achieve other benefits such as advocating the process in which loyal customers become the advocates of the business's goods and 
services (Rehman \& Afsar, 2012: 185). According to Brimpong $(2008 ; 60)$, important indicators of customer loyalty are length or duration of stay of customers; the willingness to recommend the product or institution to friends; and repurchasing products.

Empirical research (Gable, Fiorito and Topol, 2008: 14) indicates that customer loyalty is key to business success and retaining existing customers costs far less than acquiring new ones. Customer loyalty creates customer retention to improve a business's competitiveness (Gan, Cohen, Clemes \& Chong, 2006: 14). A study of Pakistani bank account holders (Rehman \& Afsar, 2012: 183) revealed that longterm success and sustainable reputation of a business depends on customer loyalty. Furthermore, results from the survey of the Bangladeshi Mobile Phone Operator Industry (Islam, 2008: 10) stressed customer retention rate as a good indicator of customer loyalty. As such, increases in customer retention rates can have a significant positive effect on market share and a business's net operating cash flow and profit. Based on these anecdotal and empirical evidence, the following relationship is hypothesised:

\section{$H^{3}$ : There is a positive relationship between achieving Customer loyalty and Increased competitiveness of SMEs.}

\section{Competitiveness}

In this study, the dependent variable is the Increased competitiveness of SMEs, which refers to a business's ability to sustain its long-term performance better than its competitors in the market, as indicated by profitability, market share, sales and growth rate. Business competitiveness can be measured using only financial indicators such as profit, market share, sales, and growth rate (Singh, Garg \& Deshmukh, 2008: 12, Man, Lau \& Chan, 2002: 125). However, there are many other indicators of competitiveness, depending on the nature of the study, industry and the size of the business, such as net worth and sales volume (Segal, Borgia \& Schoenfeld, 2010: 5). In a survey of independent Greek SMEs, business competitiveness was measured using profitability, sales growth, sales volume and market share as indicators of business success (Salavou \& Avlonitis, 2008: 7). Similarly, Jamaludin \& Hasun (2007: 6) measured competitiveness of the business by comparing the actual performance of the business sales, market share, profit, growth, demand and customer loyalty with the forecast.
In a survey of Chinese banking industry (Li \& Wang, 2007: 2), business competitiveness was measured using eight business criteria: return on total assets, return on net assets, return on sales, asset-liability ratio, total asset turnover, price-cost ratio, loan losses, and return on equity. An empirical study of furniture SMEs in Spain (Guzmán et al., 2012: 14) concluded that competitiveness of SMEs can be measured by return on investment, increase in sales, profits, and market share. Recognising the limitations of relying solely on either the financial or non-financial measures, a survey of five owners-managers of SMEs established that most owners-managers of the modern SMEs use a hybrid approach in measuring competitiveness due to their concerns on meeting the financial as well as non-financial returns. Such a combination is used to measure competitiveness against predetermined goals and time. Financial measures include profits and sales turnover while non-financial measures are the long-term growth rate and market share of the business (Chong, 2008: 7). Based on these anecdotal and empirical evidence, it can be concluded that most SMEs use profitability, market share, sales and growth rate as measures of competitiveness.

\section{Methodology}

The purpose of this section is to explain the research design and methodology that were used to address the objectives of this study.

\section{Scale development}

The factors under investigation were operationalised using reliable and valid items sourced from measuring instruments validated in previous empirical studies as indicated in Table 1 below. However, where adequate items were not obtainable, additional questions were self-generated based on thorough analysis of secondary sources to ensure that every variable in the measuring instrument was represented by sufficient items. Where necessary, the items were rephrased to make them more relevant for this study. The measuring instrument consisted of two sections. Section A consisted of 24 statements (items) related to potential outcomes of CSR engagement, using a seven-point Likerttype interval scale $(1=$ strongly disagree and $7=$ strongly agree). Section B of the questionnaire sought demographic information relating to both the respondents and the SMES in which they operate and consists of seven variables using a nominal scale.

Table 1: Sources of previously validated items used in the measuring instrument

\begin{tabular}{l|l}
\hline Factors & References \\
\hline Employee satisfaction & $\begin{array}{l}\text { Dua }(1994: 62), \text { Eybers (2010: 160), Farrington (2009: 406), Llorente and } \\
\text { Macia (2005: 66), and Tanur (1995: 427) }\end{array}$ \\
\hline Business Reputation & Fombrun, Gardberg and Sever, (2000) and Lloyd (2007:55) \\
\hline Customer loyalty & $\begin{array}{l}\text { Bloemer, Ruyter and Wetzels (1999), Donnelly (2009: 289), Ouyang (2010:6), } \\
\text { Ramzi and Mohamed (2010:5) }\end{array}$ \\
\hline Increased competitiveness & $\begin{array}{l}\text { Depperu and Cerrato (2005: 10), Konstantinidis, (2009: 2), Salavou and } \\
\text { Avlonitis, (2008: 7), Chew, Yan, and Cheah (2008:7) }\end{array}$ \\
\hline
\end{tabular}




\section{Sampling and data collection}

In this study, a non-probability sampling technique, namely purposive sampling, particularly judgmental sampling, was used to select respondents from different industrial sectors in Kampala District in Uganda, whose workforce ranged from 5-100 employees. A large number of SMEs in Uganda is located in Kampala District and the selected industrial sectors were judged to be employing a minimum of 5 and not more than 100 persons based on the definition of SMEs in this study. This data was obtained from Uganda Bureau of Statistics (UBOS 2007) Business Register Update which covered all the sectors of the Ugandan economy except the public sector and it provided an updated list of businesses employing 5 but not more than 100 persons. In this study, SMEs are considered as businesses which employ more than 5 but fewer than 100 persons. A comprehensive literature search was conducted in order to identify appropriate determinants of long-term competitiveness of SMEs. Several data searches were done at Makerere University and the Nelson Mandela Metropolitan University libraries, using databases such as EBSCO, Emerald searches, Google searches, Yahoo searches, Dissertation Abstracts, and leading CSR and SMEs Journals. The review covered journal articles, online reports and government documents.

\section{Data analysis}

Several data analysis techniques were utilised in this study to analyse data obtain from 383 usable questionnaires. An Analysis of Variance (ANOVA) was undertaken to determine the influence of demographic variables with a nominal scale on the dependent variables. An exploratory factor analysis was carried out, and Cronbach-alpha coefficients were calculated to determine the discriminant validity and reliability of the measuring instrument. The correlations were assessed using Structural Equation Modelling (SEM). The software programme SPSS 18 for Windows was used to identify representative variables and to create new variables.

\section{Results and discussion}

The results of this study are presented and discussed in the subsequent sections in relation to the study objectives.

\section{Demographic profile of respondents}

Substantial majority of respondents were males (63\%), and had been in operation between three and five years $(72 \%)$. A good number of respondents $(85 \%)$ were employed managers (CEO or functional managers) in areas such as finance or marketing, and had attained a National Certificate or Diploma $(60 \%)$. The vast majority $(67 \%)$ were operating private limited companies, employing between 11 and 20 full-time employees $(40 \%)$. The great majority of the respondents $(49 \%)$ were unwilling to disclose information regarding their annual turnover. Of those that were willing to disclose information, $26 \%$ of respondents indicated that they generated less than UGX 50 million (ZAR 161,290) per annum. Summaries of sample descriptions are presented in Table 2 below.

Table 2: Demographical profile of respondents

\begin{tabular}{|c|c|c|}
\hline Gender of respondent & Frequency & Percentage \\
\hline Male & 243 & $63 \%$ \\
\hline Female & 140 & $37 \%$ \\
\hline $\begin{array}{l}\text { Number of years in business by } \\
\text { respondent }\end{array}$ & Frequency & Percentage \\
\hline Less than three years & 0 & 0 \\
\hline Between three and 5 years & 273 & $72 \%$ \\
\hline Between 6 and 10 years & 86 & $23 \%$ \\
\hline More than 10 years & 23 & $6 \%$ \\
\hline $\begin{array}{l}\text { Position or Title in business of } \\
\text { respondent }\end{array}$ & Frequency & Percentage \\
\hline Owner (Silent Partner) & 25 & $7 \%$ \\
\hline $\begin{array}{l}\text { Owner and active manager in the } \\
\text { business }\end{array}$ & 33 & $9 \%$ \\
\hline $\begin{array}{l}\text { Employed manager (CEO or } \\
\text { functional manager) }\end{array}$ & 325 & $85 \%$ \\
\hline $\begin{array}{l}\text { Level of education of } \\
\text { respondent }\end{array}$ & Frequency & Percentage \\
\hline Ordinary level certificate & 3 & $8 \%$ \\
\hline Advanced level certificate & 12 & $3 \%$ \\
\hline National certificate or Diploma & 229 & $60 \%$ \\
\hline Bachelors degree & 127 & $33 \%$ \\
\hline Masters degree and higher & 11 & $3 \%$ \\
\hline Other & 1 &, $3 \%$ \\
\hline Form of enterprise & Frequency & Percentage \\
\hline Sole trader & 53 & $14 \%$ \\
\hline Partnership & 59 & $15 \%$ \\
\hline Private limited Company & 256 & $67 \%$ \\
\hline Trust & 12 & $3 \%$ \\
\hline Other & 2 &, $5 \%$ \\
\hline Branch/Sector & Frequency & Percentage \\
\hline Manufacturing/processing & 82 & $21 \%$ \\
\hline Business services & 76 & $20 \%$ \\
\hline Trade (retailing/wholesaling) & 41 & $11 \%$ \\
\hline Hotels and Restaurants & 75 & $20 \%$ \\
\hline Finance & 20 & $5 \%$ \\
\hline Insurance & 6 & $2 \%$ \\
\hline Education & 62 & $16 \%$ \\
\hline Health and Social works & 21 & $6 \%$ \\
\hline $\begin{array}{l}\text { Size of the business (Number of } \\
\text { full-time employees) }\end{array}$ & Frequency & Percentage \\
\hline Less than 5 & 3 &, $8 \%$ \\
\hline Between 5 and 10 & 129 & $34 \%$ \\
\hline Between 11 and 20 & 150 & $40 \%$ \\
\hline Between 21 and 50 & 73 & $19 \%$ \\
\hline More than 50 & 24 & $6 \%$ \\
\hline $\begin{array}{l}\text { Size of the business (Range of } \\
\text { Annual Turnover) }\end{array}$ & Frequency & Percentage \\
\hline $\begin{array}{l}\text { Less than UGX } 50 \text { million per } \\
\text { annum }\end{array}$ & 100 & $26 \%$ \\
\hline UGX 51-100 million per annum & 61 & $16 \%$ \\
\hline UGX 101-200 million per annum & 19 & $5 \%$ \\
\hline $\begin{array}{l}\text { More than UGX } 200 \text { million per } \\
\text { annum }\end{array}$ & 14 & $4 \%$ \\
\hline Not willing to disclose & 187 & $49 \%$ \\
\hline
\end{tabular}




\section{Discriminant validity and reliability results}

To assess the discriminant validity among the variables, all items in the questionnaire were subjected to exploratory factor analysis using the software programme SPSS 18 for Windows. Based on the relational nature of the variables, principal axis factoring with an oblique (oblimin with Kaiser normalisation) was specified as the extraction and rotation method for sub-models. While ascertaining the constructs to extract, the percentages of variance explained and the individual factor loadings were taken into account.

The exploratory factor analysis was unable to confirm all the latent variables as originally anticipated. Of the eight items intended to measure Employee satisfaction, only two items actually loaded onto it. One item loaded onto a separate factor which was renamed Stakeholder trust. Furthermore, six items were originally intended to measure the construct Business reputation but only three items loaded together onto this factor. Another item loaded onto Stakeholder trust, which refers to the service provider being trustworthy, honest and instils confidence in his stakeholders (Eid, 2011: 93). Accordingly, an additional hypothesis was formulated (see Table 3) to test this relationship. Six items were originally used to measure the construct Customer loyalty and only four items loaded together onto this factor.

In scientific research, factor loadings of 0,30 and 0,40 are considered significant for sample sizes of 200 and 350 respectively (Hair, Black, Babin, Anderson \& Tatham, 2006: 128). In the present study, factor loadings of $\geq 0,4$ were reported for all items. Accordingly, Cronbach-alpha coefficients of greater than 0,70 (Nunnally \& Bernstein 1994; Suhr \& Shay, 2009: 3) were obtained for all constructs, confirming the reliability of measuring scales. Table 3 below presents a summary of operational definitions of the factors and the details regarding the validity and reliability of the measuring instrument.

\section{Table 3: Measurement instrument analyses}

\begin{tabular}{l|l|l}
\hline Operationalisation of factors & Items & Factor loadings \\
\hline $\begin{array}{l}\text { Employee satisfaction refers to the business having employees who see their } \\
\text { part in the business as satisfying, and they enjoy the way they work together in } \\
\text { the business. }\end{array}$ & 2 & $\begin{array}{l}\text { Max: } 0,890 \\
\text { Min: } 0,857\end{array}$ \\
\hline $\begin{array}{l}\text { Business reputation refers to the business being well-known among its } \\
\text { stakeholders who also have a good opinion about the business. The business is } \\
\text { also well known for making reliable products and/or services. }\end{array}$ & 3 & $\begin{array}{l}\text { Max: } 0,812 \\
\text { Min: } 0,572\end{array}$ \\
\hline $\begin{array}{l}\text { Customer loyalty refers to the business having customers that are willing to } \\
\text { support it by recommending its products and committed to buying its } \\
\text { products/services in the future. }\end{array}$ & 4 & $\begin{array}{l}\text { Max: } 0,832 \\
\text { Min: } 0,581\end{array}$ \\
$\begin{array}{l}\text { Stakeholder trust refers to the business being regarded as trustworthy among } \\
\text { stakeholders, having stakeholders who enjoy working in the business, and } \\
\text { having customers who are willing to recommend the business to other } \\
\text { customers. }\end{array}$ & 3 & 0,738 \\
\hline
\end{tabular}

\section{Reformulated hypotheses}

Based on the results of the exploratory factor analysis, it was deemed important to modify the original hypotheses, as summarised in Table 4 below:

\section{Table 4: Reformulated hypotheses}

\begin{tabular}{ll}
\hline$H^{l}:$ & $\begin{array}{l}\text { There is a positive relationship between achieving } \\
\text { Employee satisfaction and the Increased competitiveness } \\
\text { of SMEs. }\end{array}$ \\
\hline$H^{2}:$ & $\begin{array}{l}\text { There is a positive relationship between the Business } \\
\text { reputation of SMEs and the Increased competitiveness of } \\
\text { SMEs. }\end{array}$ \\
\hline$H^{3}:$ & $\begin{array}{l}\text { There is a positive relationship between achieving } \\
\text { Customer loyalty and the Increased competitiveness of } \\
\text { SMEs. }\end{array}$ \\
\hline$H^{4}:$ & $\begin{array}{l}\text { There is a positive relationship between achieving } \\
\text { Stakeholder trust and the Increased competitiveness of } \\
\text { SMEs. }\end{array}$ \\
\hline
\end{tabular}

\section{Structural Equation Modelling results}

To establish the extent to which the proposed model represents an acceptable approximation of the data, various fit indices were utilised. These include the Satorra-Bentler scaled Chi-square $\left(\chi^{2}\right)$, the ratio of Chi-square to degrees of freedom $(\chi 2 / \mathrm{df})$, RMSEA, and the $90 \%$ confidence interval for RMSEA (Hoe, 2008: 2). The indices present proof of a model with a reasonable fit.

The empirical results of this study (see Figure 2) reveal that Employee satisfaction, Business reputation, Customer loyalty and Stakeholder trust positively influence the Increased competitiveness of SMEs. Support is therefore found for hypotheses $H^{1}, H^{2}, H^{3}$ and $H^{4}$. 


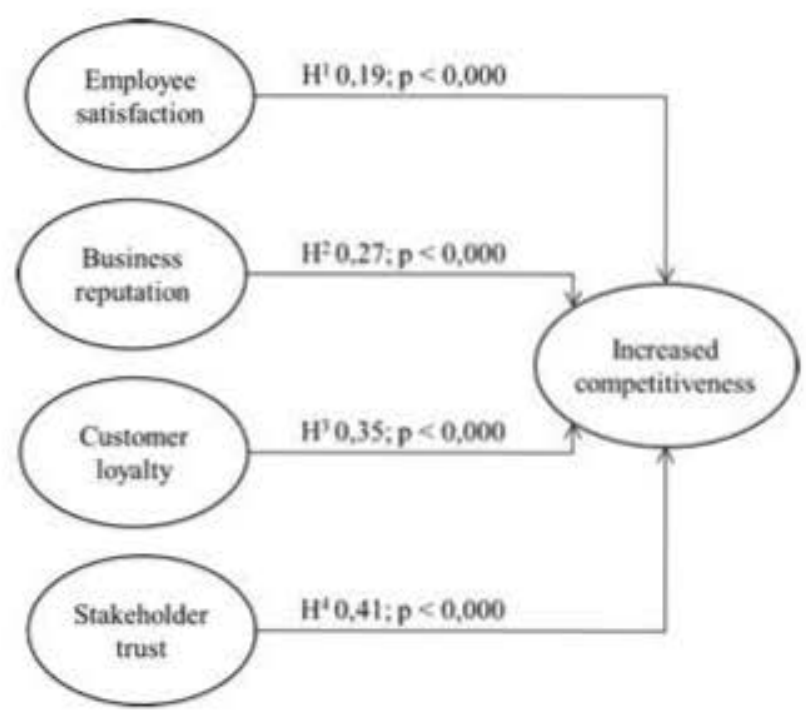

Figure 2: Empirical findings of factors determining the Increased co mpetitiveness of SMEs

From Figure 2 above, it is clear that a positive relationship (path coefficient $=0,19 ; \mathrm{p}<0.000$ ) exists between Employee satisfaction and Increased competitiveness (Hypothesis $Y^{I}$ ) of SMEs. This implies that SMEs which have employees who see their part in the business as satisfying and enjoy the way they work together, are more likely to enhanee their competitiveness in the long-run compared to those businesses that ignore the plight of their ernployees. The findings of this study are supported by previous research (Tsai et al, 2005: 9) which confirms the positive relationship between employee satisfaction and SME competitiveness. A study of Canadian SMEs (Princic \& Floyd, 2003: 12) established that good employee relationships are critical to the success of SMEs.

The present study has revealed a positive relationship between Business reputation and Inoreased competitiveness (path coefficient $=0,27 ; \mathrm{p}<0.000$ ) of SMEs. In other words, the more a business is well-known among its stakeholders for making reliable products and/or services, the more it is likely to enhance its competitiveness. Empirical results from previous research (Roberts \& Dowling, 2002: 14) revealed that superior-performing businesses have a greater chance of sustaining superior performance over time if they also possess relatively good business reputation. According to Polásek (2010: 56), the reputation of a business at its location, its image as an employer and producer certainly influences its competitiveness. Hence, Customers are more inclined to purchase the products or services from businesses which they pereeive as having favourable reputation among their competitors (Nguyen \& Leblane, 2001).

A significant positive relationship between Customer loyalty and Increased competitiveness (path coefficient $=0,35 ; \mathrm{p}<$ $0.000)$ of SMEs was revealed. This implies that a business which has customers that are willing to support it by recommending its products and/or services, and who are committed to buying its products/services in the future, is more likely to gain and sustain a competitive advantage. Sufficient evidence has been found to support the relationship. A survey of Pakistani bank account holders (Rehman \& Afsar, 2012: 183) revealed that long-term success and sustainable reputation of a business depends on customer loyalty. A survey of the Bangladeshi Mobile Phone Operator Industry (Islam, 2008: 10) revealed that increases in customer retention rates can have a significant postive effect on market share and a business's net operating cash flow and profit.

The results of this study show a significant positive relationship between Stakeholder trust and Increased competitiveness (path coefficient $=0,41 ; p<0.000$ ) of SMES (Hypothesis $H^{\text {) }}$ ). In other words, if a business is regarded as trustworthy among stakeholders, having stakeholders who erjoy working in the business and has eustomers who are willing to recommend the business to other eustomers, it is more likely to gain and sustain a competitive advantage. A survey of stakeholder groups from four different businesses in USA. (Pison \& Malhotra, 2007: 2) revealed that stakeholler trust was widely recognised as a key enabler of business sucess, and different antecedents of trust (benevolence, integrity, competence, reliability, transparency, and identification) are indeed relevant for different stakeholder types.

\section{Conclusions and recommendations}

The fundings of this study eonfurm positive relationships between Employee satisfaction Business reputation, Customer loyalty and Stakeholder trust (independent variables), and the Increased competitiveness (dependent variable) of SMEs.

The study findings reveal a significant positive influence of Employee satisfaction on the Increased competitiveness of SMEs. This result suggests that a business which has employees that see their part in the business as satisfying and enjoy the way they work together is more likely to enhance its competitiveness in the long-run. It is important for SMEs to note that different things motivate people differently, and therefore, should use multiple strategies to achieve employee satisfaction. To gain and maintain a competitive advantage, SMEs should design jobs that offer more variety and stimulation, give employee regular feedback and empower their employees to participate in decision-making to solve work-related problems.

A significant positive relationship between Business reputation and Increased competitiveness of SMEs was reported. This implies that a business which is well-known among its stakeholders for making reliable produets and/or services is more likely to merease its competitiveness. Business reputation is an intangible asset that businesses can use to ereate a competitive advantage, by distinguishing thernselves from others. SMEs ean therefore enhance their competitiveness by selling reliable products and/or services, obtaining periodic feedback regarding the brand-image of the business among stakeholders, property developing and 
managing the relationships between stakeholder groups, such as customers and employees, and establishing a pattern of open communication.

The results of this study show a significant positive relationship between Customer loyalty and Increased competitiveness of SMEs. This implies that a business which has customers that are willing to support it by recommending its products and/or services and is committed to buying its products/services in the future is more likely to gain and sustain a competitive advantage in the long-term. Increases in customer retention rates can have a significant positive effect on market share and a business's net operating cash flow and profit. Therefore, it is important for SMEs to provide outstanding customer service; stay in contact and communicate with customers regularly through different media, such as a monthly newsletter, facebook or maintaining a website; deliver more than what customers expect; and employ competent and motivated employees who are likely to provide professional and superior services to customers.
The findings of this study confirm that Stakeholder trust has a significant positive influence on Increased competitiveness of SMEs. This means that a business which is regarded as trustworthy, and has stakeholders who enjoy working with it and are willing to recommend the business to other customers is more likely to gain and sustain a competitive advantage. Building trust with various stakeholders (e.g., customers, employees, suppliers and investors) requires commitment and investment in time, human, and financial resources. Hence, SMEs can build stakeholder trust by demonstrating a high degree of transparency in their transactions, listening and honouring their promises, and demonstrating honesty and integrity towards stakeholders, no matter how difficult it might be.

Table 5 provides some general guidelines for using potential outcomes of CSR engagement that could enhance competitiveness of SMEs.

\section{Table 5: General guidelines for using potential outcomes of CSR engagement to enhance SME competitiveness}

\begin{tabular}{l|l}
\hline & Employee satisfaction guidelines: \\
\hline 1 & Have employees who are happy in their jobs. \\
\hline 2 & Have employees who enjoy working in this business. \\
\hline 3 & Have employees who see their part in this business as worthwhile. \\
\hline 5 & Have employees who see their part in this business as satisfying. \\
\hline 6 & Have employees who enjoy the way that they work together in this business. \\
\hline 8 & Have employees who find what they expected from their jobs. \\
\hline 1 & Give employees the feeling that they have achieved something. \\
\hline 2 & Give employees information about what concerns them. \\
\hline 3 & Business reputation guidelines: \\
\hline 4 & Be well-known among stakeholders. \\
\hline 5 & Be well-known for making reliable products and or services. \\
\hline 6 & Have stakeholders who have a good opinion of the business. \\
\hline 1 & Have stakeholders who regard the business as trustworthy. \\
\hline 2 & Have stakeholders who feel unfriendly towards our business. \\
\hline 3 & Cuve a reliable business reputation among stakeholders. \\
\hline 4 & Have customers who are committed to supporting our business. \\
\hline 5 & Have customers who recommend our products and services. \\
\hline 6 & Have customers who will carry on buying our products/services in the future. \\
\hline
\end{tabular}

\section{Limitations and future research}

Although the present study has attempted to make a significant contribution to the body of knowledge on SMEs, it is important to identify and consider limitations when making interpretations and conclusions. The proposed hypothesised model focuses on a few selected factors that determine the competitiveness of SMEs. Future studies could investigate various other factors such as customer satisfaction, products quality, and business relations and incorporate them into a more comprehensive model that impacts the competitiveness of SMEs. The target respondents (SME owners/managers) of this study are a limitation in itself. Given the various variables proposed in the hypothesised model, different SME stakeholders could have been investigated such as customers and employees.

\section{References}

Abor, J. \& Quartey, P. 2010. 'Issues in SME development in Ghana and South Africa', International Research Journal of Finance and Economics, 33: 218-228.

Amin, M.R. \& Banerjee, S. 2007. 'Constraints and contingencies of the small business: A comparative perspective', International Business \& Economics Research Journal, 6(9): 59-66. 
Awang, Z. 2011. 'Analyzing the effects of corporate reputation on the competitiveness of telecommunication industry using the structural equation modeling: The case of Kelantan'. Journal of Statistical Modeling and Analytics, 2(2): 29-42.

Aydin, B. \& Ceylan, A. 2008. 'The employee satisfaction in metalworking manufacturing: How do organizational culture and organizational learning capacity jointly affect it"? Journal of Industrial Engineering and Management, 1(2): 143-168.

Barnett, M.L., Jermier, J.M. \& Lafferty, B.A. 2006. 'Corporate reputation: The definitional landscape", Corporate Reputation Review, 9(1): 26-38.

Beyene, A. 2002. 'Enhancing the competitiveness and productivity of small and medium scale enterprises (SMEs) in Africa. An analysis of differential roles of national governments through improved support services', Africa Development, XXVII(3) 130-156.

Bloemer, J., Ruyter, K.D. \& Wetzels, M. 1999. 'Linking perceived service quality and service loyalty: A multidimensional perspective', European Journal of Marketing, 33 (11/12): 1082-1106.

Brimpong, M.A. 2008. 'The effect of customer satisfaction on loyalty. A case study of the First Allied Savings and Loans Ltd'. Unpublished master dissertation, Kwame Nkrumah University of Science and Technology.

Caliskan, E.N., Icke, B.T. \& Ayturk, Y. 2011. 'Corporate reputation and financial performance: Evidence from Turkey, Research Journat of International Studies, 18(1): 61-72.

Cengiz, E., Ayyildiz, H. \& Er, B. 2007. 'Effects of image and advertising efficiency on customer loyalty and antecedents of loyalty: Turkish banks sample ${ }^{*}$ Banks and Bank Systems, 2(1): 56-83.

Chew, D.A.S., Yan, S. \& Cheah, C.Y.J. 2008. 'Core capability and competitive strategy for construction SMEs in China , Chin. Manage. Stud., 2(3): 203-214.

Chong, H.G. 2008. 'Measuring performance of small-andmedium sized enterprises: the grounded theory approach", Journal of Business and Public Affairs. 2(1): 1-13.

Davies, G., Chun, R. \& Kamins, M.A. 2010. 'Reputation gaps and the performance of service organizations', Strategic Management Journal, 31(5): 530-546.

Depperu, D. \& Cerrato, D. 2005. 'Analyzing international competitiveness at the firm level: Concepts and measures'. Working Paper No. 32, Dipartimento Scienze Sociali Sezione Economia Aziendale. Universita Cattolica del Sacro Cuore, Piacenza.
Diaz-Serrano, L. \& Cabral Vieira, J.A. 2005. Low pay, higher pay and job satisfaction within the European Union: Empirical evidence from fourteen countries, IZA Discussion Papers No. 1558, Institute for the Study of Labour (IZA).

Donnelly, M. 2009. 'Building customer loyalty. A customer experience based approach in a tourism context.' Unpublished doctoral thesis, Waterford Institute of Technology.

Dua, J.K. 1994. 'Job stressors and their effects on physical health, emotional health, and job satisfaction in a university', Journal of Educational Administration, 32: 59 78.

Eberl, M. \& Schwaiger, M. 2005. 'Corporate reputation: Disentangling the effects on financial performance', European Journal of Marketing, 39(7/8): 838-854.

Eid, M.I. 2011. 'Determinants of e-commerce customer satisfaction, trust, and loyalty in Saudi Arabia', Journal of Electronic Commerce Research, 12(1): 78-93.

Eybers, C. 2010. 'Copreneurships in South African small and medium-sized family businesses. Unpublished doctoral thesis, Nelson Mandela Metropolitan University, Port Elizabeth.

Farrington, S.M. 2009. 'Sibling partnership in South African small and medium-sized family businesses'. Unpublished doctoral thesis, Nelson Mandela Metropolitan University, Port Elizabeth.

Fombrun, C.J., Gardberg, N.A. \& Sever, J.W. 2000. 'The reputation quotient: A multi-stakeholder measure of corporate reputation", The Journal of Brand Management, $7(4): 241-55$.

Gable, M.; Fiorito, S.S. \& Topol, M.T. 2008. 'An empirical analysis of the components of retailer customer loyalty programs', International Journal of Retail \& Distribution Management, 36(1): 32-49.

Gan, C.; Cohen, D.; Clemes, M. \& Chong, E. 2006. 'A survey of customer retention in the New Zealand banking industry ${ }^{3}$ Banks and Bank Systems, 1(4): 83-99.

Gaziouglu, S. \& Tanseel, A. 2002. Job satisfaction in Britain: Individual and job-related factors. Economic Research Centre Working Papers in Economics 03/03, Ankara.

Guzmán, G.M., Gutiérrez, J.S., Cortes, J.G. \& Ramírez, R.G. 2012. 'Measuring the competitiveness level in furniture SMEs of Spain', International Journal of Economics and Management Sciences, 1(11): 9-19.

Hair, J.F., Black, W.C., Babin, J.B., Anderson, R.E. \& Tatham, R.L. 2006. Multivariate data analysis. $6^{\text {th }}$ Edition. Upper Saddle River, New Jersey: Pearson/Prentice Hall. 
Harorimana, D. 2009. 'The gatekeepers' intervention in innovation and technological transfer', Electronic Journal of Knowledge Management, 7(1): 63-76.

Hatega, G. 2007. 'SME development in Uganda. Private sector foundation Uganda.' Paper presented at a Local SMEs Conference on 14th-March 2007, Sheraton Kampala.

Helm, S. 2007. 'One reputation or many? Comparing stakeholders' perceptions of corporate reputation', International Joumal of Corporate Communications, 12(3): 238-254.

Hoe, S.L. 2008. 'Issues and procedures in adopting structural equation modeling technique', Journal of Applied Quantitative Methods, 3(1): 76-83.

Islam, M.S. 2008. 'The analysis of customer loyalty in Bangladesh mobile phone operators industry', World Journal of Management, 2(2): 130-145.

Jamaludin, Z. \& Hasun, F.M. 2007. 'The importance of staff training to the SMEs' performance.' Paper presented at the International Colloquium on Business and Management (ICBM), Bangkok Palace Hotel, Bangkok, Thailand.

Karatepe, O. \& Kilic, H. 2007. 'Relationships of supervisor support and conflicts in the work-family interface with the selected job outcomes of frontline employees', Tourism Management, 28(1): 238-252.

Kishore, K., Majumdar, M. \& Kiran, V. 2012. 'Innovative HR strategies for SMEs', Journal of Business and Management, 2(6): 1-8.

Kongole, M. 2010. 'Job creation versus job shedding and the role of SMEs in economic development', African journal of Business Management, 4(11): 2288-2295.

Konstantinidis, C. 2009. 'The competitiveness of the Greek meat processing enterprises'. Paper presented at the 113 th EAAE Seminar, Chania, Crete, Greece, 3- 6, 2009.

Kovačević, B., Gajić, T. \& Penić, M. 2012. 'Job satisfaction among the employees in Novi Sad's tourist agencies', Economics of Agriculture, 2(59): 217-228.

Lee, J.; Lee, J. \& Feick, L. 2001. "The impact of switching costs on the customer satisfaction-loyalty link: Mobile phone service in Frances, Journal of Services Marketing, 15(1): $35-48$.

Li, J. \& Wang, H. 2007. 'An empirical examination of competitive advantage and corporate social responsibility. A Chinese banking industry investigation'. Proceedings of the International Conference on Wireless Communications, Networking and Mobile Computing, pp. 3292- 3295. Zhejiang Gongshang University, Hangzhou.

Liu, Y. \& Zhou, X. 2009. 'Corporate social responsibility and customer loyalty: A conceptual framework'.
Proceedings of the $6^{\text {th }}$ International Conference on Service Systems and Service Management, Xiamen University, Fujian, pp.794-798.

Llorente, R.M. \& Macia, E.F. 2005. 'Job satisfaction as an indicator of the quality of work', The Journal of SocioEconomics. 34: 656-673.

Lloyd, S. 2007. 'Corporate reputation: Ontology and measurement.' Unpublished doctoral thesis, AUT University.

Man, T.W.Y, Lau, T. \& Chan, K.F, 2002. "The competitiveness of small and medium enterprises: A conceptualization with focus on entrepreneurial competencies', Journal of Business Venturing, 17(2): 123142.

Mandl, I. 2009. 'The interaction between local employment, development and corporate social responsibility". Contract Reference No, VC/2007/0559. Vienna, January 2009.

Muhammad, M.Z., Char, A.K., Yasoa, M.R. \& Hassan, Z. 2010. 'Small and medium enterprises (SMEs) competing in the global business environment: A case of Malaysia', International Business Research, 3(1): 66-75.

Nguyen, N. \& Leblanc, G. 2001. 'Corporate image and corporate reputation in consumers' retention decision in services', Joumal of Retailing and Consumer Services, 8(3): $227-236$.

Nunnally, J.C. \& Bernstein, I.H. 1994. Psychometric theory. $3^{\text {rd }}$ Edition. New York: McGraw-Hill.

Okpara, J.O. \& Wynn, P. 2007. 'Determinants of small business growth constraints in a sub-Saharan African economy, International Review of Business Research Papers, 5(6): 195-211.

Omar, M., Williams, R.L. \& Lingelbach, D. 2009. 'Global brand market-entry strategy to manage corporate reputation", Journal of Product \& Brand Management, 18(3): $177-187$

Ouyang, Y. 2010. 'A relationship between the financial consultants' service quality and customer trust after financial tsunami ${ }^{*}$ International Research Journal of Finance and Economics, 36(2010): 75-86.

Papulova, E. \& Papulova, Z. 2006. 'Competitive strategy and competitive advantages of small and medium-sized manufacturing enterprises in Slovakia'. E-Leader, Slovakia 2006.

Pirson, M. \& Malhotra, D. 2007. What matters to whom? Managing trust across multiple stakeholder groups. Working Paper No. 39, The Hauser Centre for Non-profit Organizations, Harvard University. 
Princic, L. \& Floyd, M. 2003. 'Engaging small business in corporate social responsibility. A Canadian small business perspective on CSR. [online] URL: Www. usaskstudies.coop/ socialeconomy/.../SocialEconomyBibliography. Accessed 24 February 2006.

Polášek, D. 2010. 'Corporate social responsibility in small and medium-sized companies in the Czech Republic." Unpublished doctoral thesis, Czech Management Institute, Praha.

Ramzi, A.R. \& Mohamed, B. 2010. 'Customer loyalty and the impacts of service quality: The case of five star hotels in Jordan', International Journal of Human and Social Sciences, 5(13): 886-892.

Rehman, M. \& Afsar, B. 2012. 'Relationship among corporate image, intangible perceived quality, choosing, habit and customer loyalty', Management \& Marketing, 10(1): 183-197,

Roberts, P.W. \& Dowling, G.R. 2002. 'Corporate reputation and sustained superior financial performance', Strategic Management Journal, 23: 1077-1093.

Salavou, H. \& Avlonitis, G. 2008. 'Product innovativeness and performance: A focus on SMEs', Management Decision, 46(7): 969-985.

Saleh, A.S. \& Ndubisi, N.O. 2006. 'An evaluation of SME development in Malaysia', International Review of Business Research Papers, 2(1): 1-14.

Shamma, H.M. \& Hassan, S.S. 2009. 'Customer and noncustomer perspectives for examining corporate reputation", Journal of Product and Brand Management, 18(5): 326337.

Segal, G., Borgia, D. \& Schoenfeld, J. 2010. 'Founder human capital and small firm performance: An empirical study of founder-managed natural food stores', Journat of Management and Marketing Research, 4 (1): 71 - 83.

Singh, R.J., Garg, S.K. \& Deshmukh, S.G. 2008. "Strategy development by SMEs for competitiveness: A review", An International Journal, 15(5): 525-547.

Sirota Survey Intelligence. 2007. 'CSR boosts employee engagement boosts employee engagement". [online] URL: http://www.management-issues.com/2007/5/9/research/ social-responsibility-boosts-employee-engagement.asp.

Accessed 9 May 2007.

Suhr, D. \& Shay, M. 2009. "Guidelines for reliability, confirmatory and exploratory factor analysis'. [online] URL: Www.wuss.org/proceedings09/09WUSSProceedings/.../AN L-SuhrShay. Accessed 5 April 2009.

Szabo, A. 2008. 'The corporate social responsibility: An opportunity for SMEs'. [online] URL: http://www.unglobalcompact.org/http://www.unece.org/indu st/sme/ ResponsibleEntrepreneurship. Accessed 20 June 2008 .

Szerb, L. \& Ulbert, J. 2009. "The examination of the competitiveness in the Hungarian SME sector: A firm level analysis', Acta Polytechnica Hungarica, 6(3); 105-123.

Tanur, J.M. 1995. "Measuring employee satisfaction". Corporate surveys as practice by the State University of New York at Stony Brook.

Tsai, K., Yu, K. \& Fu, S. 2005. 'Do employee benefits really offer no advantage on firm productivity? An examination of Taiwan's shipping industry', Journal of the Eastern Asia Society for Transportation Studies, 6: 838-850.

Turyakira, P. 2012. 'Corporate social responsibility: A competitive strategy for small and medium-sized enterprises in Uganda.' Unpublished doctoral thesis, Nelson Mandela Metropolitan University, Port Elizabeth.

Tushabomwe-Kazooba, C. 2006. 'Causes of small business failure in Uganda: A case study from Bushenyi and Mbarara towns', African Studies Quarterly, 8(4): 1-13.

Uganda Bureau of Statistics (UBOS). 2007 'Business register update. A report covering all the sectors of the economy except the public sector.' [online] URL: www.ubos.org/onlinefiles/uploads/ubos/.,/20067UBRreport. Accessed 25 April 2008.

Walker, K. 2010, 'A systematic review of the corporate reputation literature: Definition, measurement, and theory', Corporate Reputation Review, 12(4): 357-387.

Whittaker, J., Burns, M., \& Beveren, J.V. 2003. 'Understanding and measuring the effect of social capital on knowledge transfer within clusters of small-medium enterprises.' Paper presented at the 16th Anmual Conference, University of Ballarat, Ballarat, Australia.

Yee, R.W.Y., Yeung, A.C.L. \& Cheng, T.C. 2010. 'An empirical study of employee loyalty, service quality and firm performance in the service industry". International Journal of Production Economics, 124(1): 109-120.

Zhang, Y. 2009. 'A study of corporate reputation's influence on consumer loyalty based on PLS-PM', International Business Research, 2(3): 28-35. 